\title{
Economic Growth in a Cross-Cultural Environment: Lessons for Selected African Countries
}

\author{
Johnson Akpan Atan Ubong Edem Effiong* \\ Department of Economics, Faculty of Social Sciences, University of Uyo, \\ P.M.B. 1017, Uyo, Akwa Ibom State, Nigeria
}

\begin{abstract}
In this paper, we examined the effect of globalization on economic growth of 25 selected African countries for the period 1991 to 2017. The index of globalization utilized was the Konjunkturforschungsstelle (KOF) Index of Globalization that takes into consideration the economic, social, and political dimensions of globalization. The study also examined the effect of globalization on unemployment in Africa. The study employed the panel unit root test, cointegration test, ARDL vector error correction mechanism (VECM), and Granger Causality test techniques. The panel unit root test reported a mixed order of integration necessitating the use of the cointegration test. The Pedroni cointegration test and the Fisher-ADF test revealed the presence of a long run relationship between globalization and economic growth in Africa. Based on the VECM, it was observed that globalization exerts a positive and significant effect on economic growth in the long run but a negative and insignificant effect in the short run. Also, globalization exerted a positive and significant effect on unemployment in the long run while in the short run, the effect was negative and significant. The Dumitrescu Hurlin Panel Causality Tests revealed the existence of a bi-directional relationship between globalization and economic growth in Africa. The policy implication of the paper is that African countries should realize the long run importance of globalization as a powerful force that drives a modern economy hence, coherent policies should be developed and geared towards managing the excesses of globalization so as to be moving along with the ever evolving world.
\end{abstract}

Keywords: Economic Globalization, Political Globalization, Foreign Direct Investment, Financial Liberalization, Panel Regression, Social Globalization

DOI: $10.7176 / \mathrm{JEP} / 11-24-05$

Publication date: December $31^{\text {st }} 2020$

\section{Introduction}

A cross-cultural environment is characterized by globalization in both economic, political, and social spheres. Globalization can be viewed as a process of creating connections through the exchange of information, ideas, capital and goods (Clark, 2000; Norris, 2000; and Keohane and Nye, 2000), leading to integration of national economies, cultures, technologies and governance, eventually clouding economic precincts between nations and producing a complex system of conjoint interdependence (Ying, Chang and Lee, 2014). The concept of globalization can be viewed from the standpoints of Realism, Liberalism, and Marxism. To the school of Realism, the concept believes that the structure of the international system is based on government and logic and principles governing this globalized world are more or less frenzied while to the Liberalism school, the structure of the international system is multi-centre, principles and logic underlying it has the intricacy and not indiscretion and believe in distribution of equal power. The Marxist school considers globalization with some as similar and some even consider it equal with the Americans (Omidvar and Daryabeigi, 2011). Also, the school considers the structure of the system as central world and called logic and principles governing it as the form and manner of commerce and historical production (Majidi, 2017).

Globalization can be viewed from diverse angles - economic, social and political. The issue of globalization in the economic, social and political arena has been drawing responsiveness of policy analyst since the 1970s, with particular lift after the end of the Cold War (Eth, 2019). From the economic perspective, it hinges on 'the high growth of global trade and trade liberalization in developing countries, transfer and fast development of technology, increase international competition and subsequently increase economic efficiency at domestic and international level, extent division of international labour, escalating the flow of foreign direct investment, financial markets liberalization and privatization that each of them play a significant role in the economic development of communities; leading to a conjunction and assimilation of national economies in the global economy' (Majidi, 2017). Despite the aforementioned positive effects, globalization had led to economic crisis - financial crisis and unemployment crisis; worsening environment pollution by the rich countries; as well as exaggerate challenge between rich and poor countries (Taheri and Taheri, 1964). At the political scene, the phenomenon will cause to create many possibilities for the alliance of democracy and human rights at the national level and the instituting of world peace (Majidi, 2017). However, this phenomenon can create conflicts in societies such as egoistic leaders, undermining the rule of governments, increasing engrossment of multinational companies and influence of foreign countries thus making the activities and support policies of governments as an independent political unit to limit their economic strength (Nahavandian and Ghanbari, 2004). 
The social dimension of globalization is based on cultural and technological shift. Thus, increasing growth of technology and mass media, internet and satellites caused compression of time and space and closing culture of countries and has formed the overriding culture in the global level, leading to unescapable expansion of communications and consequently increasing reduction of gaps, globalization of challenges and opportunities and behaviour patterns in different fields, the global spread of communications, identity categories and interact and affect them in worldwide and the emergence of global identity (Akhtar, 2007). Meanwhile, Pishgah (2002) has noted that "social globalization, through individual actions, will help to progress social status and lead to economic participations, public service, volunteerism activities and other social activities that improve the living position of all citizens that influence economic growth of countries" (Majidi, 2017).

Thus, the question of whether globalization have an effect on economic growth has been discussed in the literature. One of the negative effect of globalization has been linked to the issue of brain drain in developing countries (Farlex, 2009). This is due to the greater opportunities prevalent in developed countries which therefore magnets talents inherent in the developing countries. This made scholars to criticize the phenomenon on the basis that it served the interests of developed countries and large companies to the impairment of developing countries and small companies (Majidi, 2017). Also, even though globalization generates opportunities for some country's economic growth, it also triggers off poverty, inequality, and negative economic growth for others (Kilic, 2015). The report of World Bank (2017a) in regards to South Asia has counter this idea of globalization-led poverty by asserting that the prospects for the region are better than it seems and globalization has been good for development, and trade has been crucial to poverty reduction. However, globalization offers substantial benefits in the area of greater freedom of choice, lower prices of goods, and higher income for individuals (Bhattacharya, 2004). Thus, Dreher (2005) contended that globalization promotes economic growth.

Africans cannot be left out of the benefits which accrue from globalization. However, most of the writings on the area have been based on the negative effect of globalization on Africa's growth potential. The key issue behind this can be linked to the narrow definition of globalization as merely trade openness and the notion that Africa exports basically primary products while her import are mostly manufactures. This paper seeks to bridge this gap by following the conventional conceptualization of globalization on the three core dimensions of economic, political and social dimensions based on the Konjunkturforschungsstelle (KOF) globalization index. The KOF Globalization Index developed by Dreher (2006) and later upgraded by Dreher, Gaston and Martens (2008) ranges between zero to one hundred. The index apportioned 36\% to economic dimension; $37 \%$ to social dimension; and $27 \%$ to political dimension (KOF Index of Globalization, 2017). It is clear from this that linking globalization to only trade openness amounts to studying a small proportion of the economic dimension and generalizing the effect obtained. This study avoids this mistake and incorporates the three dimensions in the analysis.

Most of the empirical studies on the effect of globalization on economic growth have been done in Asian countries. Meanwhile, this study seeks to investigate the effect of globalization on economic growth of 25 selected African countries. The globalization index utilized in the study is the KOF Globalization Index and the growth rate of gross domestic product is used as a proxy for economic growth. Also, some scholars have reported that globalization triggers inequality, poverty and negative economic growth hence, this study also seeks to investigate the effect of globalization on unemployment in Africa. Since globalization should be viewed as a process, this study investigates the effect of globalization on economic growth and employment in both the short run and long run. The study went further to examining the direction of causality between globalization and economic growth in Africa.

\section{Literature Review}

\subsection{Theoretical Literature}

Several growth theories have emanated ever since the publication of Adam Smith's Wealth of Nations in 1776. The Harrod-Domar growth model stressed the importance of increased savings rate if an economy tends to grow. Based on this growth model, African countries needs to increase her savings rate and reduce her capital-output ratio to attain the desirable level of economic growth. Other theories include the Lewis two-sector model, the Neoclassical dependence model, the false paradigm model and the dualistic development thesis. Meanwhile, this study is based on the Solow neoclassical growth theory. In this model, there is a diminishing returns to each factor of production but constant returns to scale hence, exogenous technological change generates long term economic growth (Torado and Smith, 2011).

According to this traditional neoclassical theory, output growth results from: (i) increases in labour quantity and quality (through population growth and education), (ii) increase in capital (through saving and investment), and (iii) improvements in technology. As noted by Torado and Smith (2011), closed economies, an economy in which there is no foreign trade transactions or other economic contacts with the rest of the world, with lower savings rate grow more slowly in the short run than those with high savings rates and tend to converge to lower per capita income levels. Open economies, an economy that practices foreign trade and has extensive financial and nonfinancial contacts with the rest of the world, on the contrary experience income convergence at higher levels 
as capital flows from rich countries to poor countries where capital-labour ratios are lower and thus returns on investments are higher. Based on the neoclassical growth theory, it follows that by impeding the inflow of foreign investment, the heavy-handedness of many developing countries' governments will impede growth in economies of the developing world. Further, openness is said to encourage greater access to foreign production ideas that can raise the rate of technological progress (Torado and Smith, 2011). The Slow neoclassical growth model is adopted in this study because it clearly indicates the relationship between globalization and economic growth.

\subsection{Empirical Literature}

Dreher (2006) examined whether globalization affect economic growth based on the economic, social and political dimensions. The study utilized panel data form 123 countries for the period 1970 to 2000 . The result from the panel data analysis technique revealed that for sure, globalization stimulates economic growth while economic integration does not.

In Sub-Saharan Africa, Barry (2010) analysed the influence of KOF globalization index on economic growth of 41 countries for the period 1995 to 2005. Using the Ordinary Least Squares (OLS) method of estimation, the study recounted a positive, though insignificant, effect of globalization on economic growth of Sub-Saharan Africa.

In the European Union, Polasek and Sellner (2011) investigated the effect of globalization on the economic growth of 27 EU countries between 2001 and 2006. The study utilized the Spatial Chow - Lin Procedure and observed that globalization, measured as foreign direct investment and trade gap, affects many region's economic growth positively.

Bhaskara and Krishna (2011) investigated the effect of the three dimensions of globalization (political, economic, and social) on economic growth of 21 low-income African countries between 1992 to 2010 using the panel data approach. The result depicts that globalization has a positive and significant effect on growth. Likewise, Rao and Vadlamannati (2011) carried out the same research on 12 low-income African countries and also reported a positive and significant effect of globalization on economic growth.

Fagheh and Afshar (2012) investigated the relationship between economic globalization and economic growth in 21 countries of Middle East and North Africa (MENA) using panel data through $1970-2009$. The results showed that globalization has had a significant positive effect on economic growth in the MENA.

Razavi and Salimi (2013) examined the effects of economic globalization on economic growth using vector autoregressive (VAR) model in Iran for the period 1978 to 2011. The results revealed that trade liberalization and financial indicators have positive and significant effect on economic growth. In the same vein, Ashurizadeh, Maqdasi and Razavi (2013) investigated the effects of economic globalization and foreign trade on economic growth by using VAR. They observed that the globalization of the economy in the short term has weak effect on economic growth but exerted a $21 \%$ long-term effect on economic growth.

In Central and Eastern Europe, Gurgul and Lach (2014) observed a positive effect of globalization on economic growth. However, the social and economic globalization exerted a stronger positive effect on economic far more than political globalization.

Ying, Chang and Lee (2014) utilized the panel data analysis to examine the influence of short run dynamics and long-run equilibrium relationships between globalization and the growth of Association of Southeast Asian Nations (ASEAN) between 1970 and 2008 using Pendroni cointegration test and the panel fully modified OLS (FMOLS). The Pedroni cointegration test revealed that there exists a strong integrated relationship between globalization and economic growth while the FMOLS revealed that the elasticity of economic growth vis-à-vis globalization is 1.48 indicating a positive and significant effect of globalization on economic growth. Further, the study revealed that social globalization has a negative and significant effect on economic growth, while political globalization has an insignificant negative effect.

Kilic (2015) examined the effect of the three dimensions of globalization - economic, social and political on the economic growth of 74 developing countries for the period 1981 to 2011 . The study employed the fixed effects least squares dummy variable panel regression and Dumitrescu and Hurlin (2012) granger Causality test. The results of his study revealed that economic growth is positively affected by the economic and political globalization, while social globalization impacts economic growth negatively. Further, the paper observed a bidirectional causal relationship between political and social globalization and economic growth, whereas oneway causality exists between social globalization and economic growth.

In examining the impact of globalization on economic growth of three South Asian countries (Pakistan, India, and Bangladesh) for the period 1981 to 2011, Maqbool-ur-Rahman (2015) employed the OLS and Granger causality techniques, and observed that globalization and economic growth both affect each other and demonstrates bidirectional causality in India, while Pakistan and Bangladesh present unidirectional causality between globalization and economic growth.

Majidi (2017) analysed the effect of the three dimensions of globalization on economic growth in 100 developing countries for the period 1970 to 2014 . The results showed that political globalization exerts a negative and significant effect on economic growth in upper middle income countries while economic and social 
globalization had an insignificant effect on economic growth. Further, the effect of total and political globalization on economic growth in developing countries with lower middle income is positive and significant but economic and social globalization factors have no significant effect.

In a recent study, Hasan (2019) investigated the impact of globalization on economic growth of South Asian countries from 1971 to 2014. The study employed cross-sectional dependence test, Cross Sectional Augmented Dickey-Fuller (CADF) unit root test, and Pooled Mean Group (PMG) panel cointegration model. The result indicated that globalization, economic globalization, and political globalization promote economic growth in the long run. However, the dimensions of globalization have no short run significant effect.

Based on the empirical literature, it is observed that majority of the studies reported a positive and significant effect of globalization on economic growth. However, there have been dearth of empirical literature in Africa as a whole. The few, such as Barry (2010), Bhaskara and Krishna (2011), Vadlamannati (2011), and Fagbeh and Afshar (2012), utilized either OLS approach or trade openness as a measure for globalization. This study therefore fills this gap by employing a more lucid approach to examine both the short run and long run effects of globalization on economic growth in Africa. Also, the study will examine the effect of globalization on inequality (unemployment) in Africa along with determining the causal relationship between globalization and economic growth.

\section{Methodology}

3.1. Model Specification

In examining the effect of globalization on economic growth of selected African countries, the model for the study is specified as follows:

RGDPG $=\mathrm{f}($ KOFGI, FDIN, INFL, UNMR) -

Equation (I) states that the growth rate of real gross domestic product (RGDPR) is a function of globalization (KOFGI), foreign direct investment, (FDIN), inflation rate (INFL) and unemployment rate (UNMR). Transforming Equation (1) into its estimable form gives:

$\mathrm{RGDPG}=\lambda+\beta_{1} \mathrm{KOFGI}+\beta_{2} \mathrm{FDIN}+\beta_{3} \mathrm{INFL}+\beta_{4} \mathrm{UNMR}+\mu-$

Where $\lambda$ is the intercept of the regression line, $\beta$ s are the parameters to be estimated, and $\mu$ is the error term which is assumed to be normally distributed.

Also, in investigating the effect of globalization on unemployment in Africa, the simple regression model is specified as:

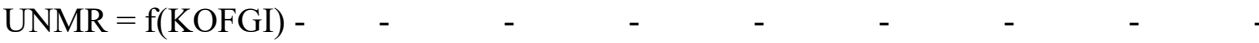

Which transforms to

$\mathrm{UNMR}=\vartheta_{0}+\vartheta_{1} \mathrm{KOFGI}+\mu-$

\subsection{A priori Expectations}

From Equation (2) and (4), it is expected that $\beta_{1}<0, \beta_{2}>0, \beta_{3}>0, \beta_{4}<0$, and $\vartheta_{1}<0$.

\subsection{Sources of Data}

The study utilized secondary data for the period 1991 to 2017 for twenty-five (25) selected African countries. The selected countries include Algeria, Angola, Benin, Burkina Faso, Cameroon, Central African Republic, Cote d'Ivoire, Egypt, Equatorial Guinea, Ethiopia, Gambia, Ghana, Kenya, Madagascar, Mauritania, Morocco, Mozambique, Nigeria, Senegal, Sierra Leone, South Africa, Sudan, Tanzania, Tunisia and Zambia. The data include growth rate of real gross domestic product (a proxy for economic growth), KOF Globalization Index (a proxy for globalization - cross-cultural environment), foreign direct investment, inflation rate and unemployment rate.

Data for this study were obtained from the World Development Indicators, a publication of World Bank Group, and KOF Swiss Economic Institute. In particular, the growth rate of real gross domestic product (RGDPG), foreign direct investment (FDIN), and unemployment rate (UNMR) were obtained from the World Development Indicators (2018) while KOF Globalization Index (KOFGI) was obtained from Savina, Haelg, Potrafke, and Sturm (2019). The KOF Globalization Index (KOFGI) captures the three core dimensions of globalization namely: economic, social and political dimensions.

\subsection{Estimation Issues}

Here, issues pertaining to the analysis of the data are presented. Such include panel unit root test, panel cointegration test, panel ARDL vector error correction mechanism, and panel Granger Causality test.

\subsubsection{Panel Unit Root Test}

The panel unit root test for this study is done on the basis of both individual and common sample. At the common sample, the study utilized the panel unit root test approach developed by Levin, Lin and Chu (2002) while at the individual unit root process, the study employed the unit root test developed by Im, Persaran and Shin (2003). The 
null hypothesis for the test is that the data are non-stationary. Meanwhile, the equation for panel unit root test based on Levin, Lin and Chu (2002) is specified as follows:

$\Delta Y_{i t}=\alpha_{i}+\beta_{\mathrm{i}} Y_{i, t-1}+\delta_{\mathrm{i}} \mathrm{t}+\sum_{j=1}^{k} \gamma_{i j} \Delta Y_{i, t-j}+\mu_{i t}-\quad-\quad-_{-} \quad-\quad-\quad$ -

Where $\Delta$ is the first difference operator, $\mathrm{Y}_{\mathrm{it}}$ is the variable of interest, $\mu_{\mathrm{it}}$ is the disturbance term (which is assumed to be white-noise) with a variance of $\sigma^{2}, \mathrm{i}=1,2,3, \ldots, \mathrm{N}$ indexes country and $\mathrm{t}=1,2,3, \ldots, \mathrm{T}$ indexes time. The null $\left(\mathrm{H}_{0}\right)$ and alternative $\left(\mathrm{H}_{1}\right)$ hypothesis for the stationarity of the panel data set from Equation $(5)$ is given as:

$\left\{H_{0}: \beta_{i}=1\right.$.

$\left\{H_{1}: \beta_{i} \neq 1\right.$;

Where the alternative hypothesis imply that $Y_{i t}$ is stationary. The test is based on ADF test which assumes homogeneity in the dynamics of the autoregressive coefficients for all panel units with cross-sectional independence (Levin, Lin and Chu, 2002).

To increase the power of the panel unit root test in a finite sample, Levin Lin and Chu (2002) also specified another equation as follows:

$\Delta Y_{i t}=\alpha_{i}+\beta_{\mathrm{i}} Y_{i, t-1}+\delta_{\mathrm{i}} \mathrm{t}+\sum_{j=1}^{k} \gamma_{i j} \Delta Y_{i, t-j}+\mu_{i t}-\quad-\quad-\quad-\quad-\quad \quad-$

From Equation (6), the null and alternative hypothesis are stated as follows:

$\left\{H_{0}: \beta_{1}=\beta_{2}=\cdots=\beta=1\right.$

$\left\{H_{1}: \beta_{1}=\beta_{2}=\cdots=\beta \neq 0\right.$

The equation of Im Perasan and Shin (2003) was based on the mean group and employed the t statistic of the estimated $\beta$ in Equation (4) which was utilized in performing a $Z$ test. The $Z$ test produces a $Z$ statistic which converges to a normal distribution.

3.4.2. Panel Cointegration Test

In examining the existence of a long run relationship (cointegration), this paper adopted the heterogeneous panel cointegration test proposed by Pedroni (2004) and Fisher-ADF test. The heterogeneous panel cointegration test allows various cross-sectional interdependences along with other different individual effects to establish the cointegration based on two kinds of test statistics namely: pooling residuals within the dimension of the panel and pooling residuals between dimension. The within-dimension is based on Panel v-Statistic, Panel rho-Statistic, Panel PP-statistic and Panel ADF-Statistic while the between-dimension is based on Group rho-Statistic, Group PP-Statistic and Group ADF-Statistic.

\subsubsection{Panel Vector Error Correction Mechanism}

The Vector Error Correction Mechanism employed is based on the Autoregressive Distributive Lag (ARDL) approach so as to separate the short term and the long term effects. In this way, we are able to detect both the short run and the long run dynamic relationships existing between economic growth and explanatory variables in the model. The model to be estimated is specified in its general form as follows:

$\triangle R G D P G_{i, t}=\varphi_{\mathrm{i}, \mathrm{j}}+\sum_{i=1}^{m} \emptyset_{i, k} \Delta X_{i, t}+\lambda_{\mathrm{i}} \mathrm{ECM}_{\mathrm{i}, \mathrm{t}-1}+\mu_{\mathrm{i}, \mathrm{t}}-$

Where $\Delta$ is the first difference operator; $\varphi_{i, j}(j, k=1,2, \ldots, N)$ represents the fixed country effect; $i(i=1, \ldots, m)$ is lag length determined by the Schwarz information Criterion (SIC); $\mathrm{X}_{\mathrm{i}, \mathrm{t}}$ is the vector of regressors; $\mathrm{ECM}_{\mathrm{i}, \mathrm{t}-1}$ is the estimated lagged error correction mechanism (ECM) derived from the long run cointegrating relationship; $\lambda_{i}$ is the adjustment coefficient; and $\mu_{\mathrm{i}, \mathrm{t}}$ is the disturbance term, which is assumed to be normally distributed with a zero mean and a constant variance.

\subsubsection{Panel Granger Causality Test}

In examining the direction of causality between globalization and economic growth in Africa, the paper employed the Dumitrescu-Hurlin (HD) Panel Causality Tests. The HD provide an extended test which is designed to detect causality in panel data (Lopez and Weber, 2017). The regression is carried out with the following equation:

$y_{i t}=\alpha_{i}+\sum_{k=1}^{k} \beta_{i k} y_{i, t-k}+\sum_{k=1}^{k} \gamma_{i k} x_{i, t-k}+\varepsilon_{i, t}-\quad-\quad \quad-\quad \quad-\quad$ -

Where $x_{i, t}$ and $y_{i, t}$ are the observations of two stationary variables for country $\mathrm{i}$ in period t. Coefficients are allowed to differ across individuals but are assumed time-variant. The lag order, $\mathrm{k}$, is assumed to be identical for all individuals and the panel must be balanced (Lopez and Weber, 2017). The null hypothesis is defined as:

$$
H_{0}: \gamma_{i 1}=\gamma_{i 2}=\cdots=\gamma_{i k}=0 \quad \forall_{i}=1, \ldots, \mathrm{N}
$$

Which in fact states the absence of causality. The alternative hypothesis is given as:

$$
\begin{array}{ll}
H_{1}: \gamma_{i 1}=\gamma_{i 2}=\cdots=\gamma_{i k} \neq 0 & \forall_{i}=1,2, \ldots, N_{1} \\
\gamma_{i 1} \neq 0 \text { or } \ldots \text { or } \gamma_{i k} \neq 0 & \forall_{i}=N_{1}+1, \ldots, N
\end{array}
$$

Where $N_{1} \in[0, N-1]$ is unknown. If $N_{1}=0$, there is causality for all individuals in the panel. $N_{1}$ is strictly less than $\mathrm{N}$, otherwise there is no causality for all individuals and $H_{1}$ reduces to $H_{0}$.

\section{Empirical Findings}

4.1. Descriptive Statistics

The descriptive statistics are presented in Table 1. 
Table 1: Descriptive Statistics of the Panel Data

\begin{tabular}{l|ccccc}
\multicolumn{1}{l}{} & RGDPG & KOFGI & FDIN & $I N F L$ & UNMR \\
\hline Mean & 4.644146 & 46.95060 & 3.938123 & 26.96843 & 8.820262 \\
Median & 4.306880 & 46.54218 & 1.898935 & 6.244150 & 7.609000 \\
Maximum & 149.9730 & 70.63972 & 161.8238 & 4145.106 & 33.47300 \\
Minimum & -36.03743 & 22.70437 & -6.057209 & -30.85616 & 0.599000 \\
Std. Dev. & 8.408037 & 10.39579 & 9.538807 & 202.6725 & 6.463469 \\
Skewness & 8.829002 & 0.168938 & 9.538788 & 16.57566 & 1.457691 \\
Kurtosis & 145.0633 & 2.515928 & 131.8339 & 304.1418 & 5.137635 \\
Jarque-Bera & 567848.4 & 9.655976 & 469992.0 & 2543220. & 362.1183 \\
& $(0.0000)$ & $(0.0080)$ & $(0.0000)$ & $(0.0000)$ & $(0.0000)$
\end{tabular}

Source: Output Extracted from Eviews 10.

Following Table 1, the average growth rate of real gross domestic product for the 25 African countries is $4.64 \%$ with a standard deviation of $8.41 \%$. Also, the index of globalization averaged $46.95 \%$ with a standard deviation of $10.40 \%$. Other variables can be discussed in a similar pattern by looking at Table 1 . A total of 665 observations were made. All the variables are reported to be positively skewed and normally distributed as represented by the significance of the Jarque-Bera statistic at the $1 \%$ level of significance.

\subsection{Correlation Matrix}

The essence of the correlation matrix is to observe whether there are high correlations existing among the explanatory variables. This is to assist in detecting whether there will be a problem of multicollinearity. The result is presented in Table 2 .

\begin{tabular}{c|ccccc}
\multicolumn{5}{c}{ Table 2: Correlations Result } \\
\multicolumn{2}{c}{ RGDPG } & KOFGI & FDIN & INFL & UNMR \\
\hline RGDPG & 1.0000 & 1.0000 & & & \\
KOFGI & 0.0228 & -0.0232 & 1.0000 & 1.0000 & \\
FDIN & 0.6899 & -0.1014 & 0.0166 & 0.1536 & 1.0000
\end{tabular}

Source: Output Extracted from Eviews 10.

From Table 2, all the explanatory variables exhibit lower degree of correlations among them. For instance, there are very low negative correlations between KOFGI and FDIN (-0.0232); KOFGI and INFL (-0.1014); and FDIN and UNMR (-0.0443); while there are low positive correlations between KOFGI and UNMR (0.2766); FDIN and INFL (0.0166); and INFL and UNMR (0.1236). Meanwhile, all the variables correlate perfectly with themselves yielding the perfect positive correlation coefficients of 1.0000 .

\subsection{Panel Unit Root Test}

The result of the panel unit root test by Levin, Lin and Chu (2002) and Im, Pesaran and Shin (2003) are presented in Table 3.

Table 3: Common Unit Root and Individual Unit Root Test Result

\begin{tabular}{|c|c|c|c|c|c|c|}
\hline \multicolumn{3}{|c|}{$\begin{array}{l}\text { Individual Unit Root Process } \\
\text { (Im, Pesaran and Shin W-stat) }\end{array}$} & \multicolumn{4}{|c|}{$\begin{array}{l}\text { Common Unit Root Process } \\
\text { (Levin, Lin \& Chu t*) }\end{array}$} \\
\hline Variable & Level & $\begin{array}{c}\text { First } \\
\text { Difference }\end{array}$ & Variable & Level & $\begin{array}{c}\text { First } \\
\text { Difference }\end{array}$ & $\begin{array}{l}\text { Order of } \\
\text { Integration }\end{array}$ \\
\hline RGDPG & $\begin{array}{l}-12.0013 \\
(0.0000)^{* *}\end{array}$ & ------ & RGDPG & $\begin{array}{l}-11.5905 \\
(0.0000)^{* *}\end{array}$ & -------- & $\mathrm{I}(0)$ \\
\hline KOFGI & $\begin{array}{l}0.79024 \\
(0.7853) \\
\end{array}$ & $\begin{array}{l}-15.2500 \\
(0.0000)^{* *}\end{array}$ & KOFGI & $\begin{array}{l}-4.94123 \\
(0.0000)^{* *}\end{array}$ & $\begin{array}{c}-12.7497 \\
(0.0000) * *\end{array}$ & $\mathrm{I}(1)$ \\
\hline FDIN & $\begin{array}{c}-7.48690 \\
(0.0000)^{* *}\end{array}$ & --------- & FDIN & $\begin{array}{c}-6.36138 \\
(0.0000)^{* *}\end{array}$ & ------- & $\mathrm{I}(0)$ \\
\hline INFL & $\begin{array}{l}-37.7238 \\
(0.0000)^{*}\end{array}$ & ----- & INFL & $\begin{array}{l}-138.520 \\
(0.0000)^{* *}\end{array}$ & ----- & $\mathrm{I}(0)$ \\
\hline UNMR & $\begin{array}{l}1.23402 \\
(0.8914)\end{array}$ & $\begin{array}{l}-11.8161 \\
(0.0000)^{* *}\end{array}$ & UNMR & $\begin{array}{l}0.49825 \\
(0.6908)\end{array}$ & $\begin{array}{c}-12.2541 \\
(0.0000)^{* *}\end{array}$ & $\mathrm{I}(1)$ \\
\hline
\end{tabular}

Note: ** and * denotes significance at the $1 \%$ and $5 \%$ level respectively.

Source: Output extracted from Eviews 10.

From Table 3, the result of the unit root test (both common and individual) indicates that all the variables, 
except index of globalization (KOFGI) and unemployment rate, were stationary at level. However, KOFGI and UNMR became stationary after first difference. This mixture of levels and first difference order of integration necessitates the test for cointegration to determine the existence of a long-run equilibrium relationship.

\subsection{Panel Cointegration Tests}

The result of the Pedroni (2004) panel cointegration test is presented in Table 4.

Table 4: Panel Cointegration Result

\begin{tabular}{|c|c|c|c|c|}
\hline \multicolumn{2}{|c|}{ Panel Co-integration Test } & Individual Intercept & \multicolumn{2}{|c|}{ Individual Intercept and Trend } \\
\hline \multicolumn{5}{|c|}{ Within-Dimension } \\
\hline \multicolumn{2}{|l|}{ Panel v-Statistic } & $2.290879(0.0110)^{*}$ & \multicolumn{2}{|c|}{$-0.734687(0.7687)$} \\
\hline \multicolumn{2}{|l|}{ Panel rho-Statistic } & $-4.817258(0.0000)^{* *}$ & \multicolumn{2}{|c|}{$-2.905232(0.0018)^{* *}$} \\
\hline \multicolumn{2}{|l|}{ Panel PP-Statistic } & $-17.89217(0.0000)^{* *}$ & \multicolumn{2}{|c|}{$-18.62754(0.0000)^{* *}$} \\
\hline \multicolumn{2}{|l|}{ Panel ADF-Statistic } & $-14.42222(0.0000)^{* *}$ & \multicolumn{2}{|c|}{$-14.60510(0.0000)^{* *}$} \\
\hline \multicolumn{5}{|c|}{ Between-Dimension } \\
\hline \multicolumn{2}{|l|}{ Group rho-Statistic } & $-2.645996(0.0041)^{*}$ & \multicolumn{2}{|c|}{$-0.785603(0.2160)$} \\
\hline \multicolumn{2}{|l|}{ Group PP-Statistic } & $-15.62821(0.0000)^{* *}$ & \multicolumn{2}{|c|}{$-14.62330(0.0000)^{* *}$} \\
\hline \multicolumn{2}{|l|}{ Group ADF-Statistic } & $-8.166632(0.0000)^{* *}$ & \multicolumn{2}{|c|}{$-6.480546(0.0000)^{* *}$} \\
\hline \multicolumn{5}{|c|}{ Combined Fisher - ADF Test } \\
\hline No. of CE(s) & Trace Test & \begin{tabular}{l|l|} 
& Probability \\
\end{tabular} & Max-Eigen Value & Probability \\
\hline$r=0$ & 537.6 & $0.0000^{* *}$ & 345.5 & $0.0000 * *$ \\
\hline $\mathrm{r}>1$ & 260.4 & $0.0000 * *$ & 174.0 & $0.0000 * *$ \\
\hline$r>2$ & 125.9 & $0.0000 * *$ & 105.3 & $0.0000 * *$ \\
\hline$r>3$ & 64.63 & $0.0548^{*}$ & 49.96 & 0.3956 \\
\hline$r>4$ & 81.64 & $0.0018 * *$ & 81.64 & $0.0018 * *$ \\
\hline
\end{tabular}

Note: Probabilities are computed using asymptotic Chi-square distribution.

** and $*$ indicates $1 \%$ and $5 \%$ level of significance respectively.

Source: Output from Eviews 10.

From Table 4, the upper section indicates the rejection of the null hypothesis of no cointegrating relationship at the $1 \%$ and $5 \%$ levels since all the statistics are significant. In confirmation to this, the Fisher-ADF statistic indicates the existence of five cointegrating equations, CE(s). Both the Trace Statistics and the Max-Eigen values supports the fact that there is cointegration. Thus, there is a long run relationship between globalization and economic growth. However, this relationship can only be truly identified through the use of the vector error correction mechanism.

\subsection{Panel Error Correction Mechanism}

\subsubsection{Panel Error Correction Mechanism for Equation (2)}

The result of the error correction mechanism to capture the effect of globalization on economic growth in Africa is presented in Table 5.

Table 5: Error Correction Mechanism Result for Equation (2)

\begin{tabular}{|c|c|c|c|c|}
\hline Variable & Coefficient & Standard Error & t-statistic & Probability \\
\hline \multicolumn{5}{|c|}{ Long Run Equation: RGDPG = 0.057KOFGI + 0.131FDIN + 0.003INFL + 0.127UNMR } \\
\hline KOFGI & 0.0569 & 0.0166 & 3.4211 & $0.0007 * *$ \\
\hline FDIN & 0.1308 & 0.0489 & 2.6780 & $0.0076^{* *}$ \\
\hline INFL & 0.0031 & 0.0022 & 1.4070 & 0.1600 \\
\hline UNMR & 0.1268 & 0.0329 & 3.8506 & $0.0001^{* *}$ \\
\hline \multicolumn{5}{|c|}{$\begin{array}{c}\text { Short Run Equation: } \begin{array}{c}\Delta R G D P R=-0.209-0.053 \Delta K O F G I+0.111 \Delta F D I N-0.047 \Delta I N F L-0.586 \Delta U N M R \\
-0.782 E C M(-1)\end{array}\end{array}$} \\
\hline $\operatorname{ECM}(-1)$ & -0.7821 & 0.0697 & -11.219 & $0.0000^{* *}$ \\
\hline $\mathrm{D}$ (KOFGI) & -0.0528 & 0.2836 & -0.1863 & 0.8523 \\
\hline $\mathrm{D}(\mathrm{FDIN})$ & 0.1112 & 0.1500 & 0.7413 & 0.4588 \\
\hline D(INFL) & -0.0467 & 0.0507 & -0.9200 & 0.3580 \\
\hline D(UNMR) & -0.5856 & 1.0596 & -0.5527 & 0.5807 \\
\hline $\mathrm{C}$ & -0.2093 & 0.5518 & -0.3794 & 0.7046 \\
\hline
\end{tabular}

Note: $* *$ and $*$ indicates $1 \%$ and $5 \%$ level of significance respectively.

Source: Output Extracted from Eviews 10.

Table 5 reveals both the long run and the short run dynamic relationships between economic growth and the explanatory variables. It is observed that globalization (KOFGI) exerts a negative and insignificant effect on economic growth in the short run but exert a positive and significant effect on economic growth in the long run. 
In the long run, a unit percentage increase in globalization will lead to a $5.69 \%$ increase in economic growth. This positive and significant effect of globalization on economic growth in Africa is in line with the findings of Ying, Chang and Lee (2014), Bhaskara and Krishna (2011), Gurgul and Lach (2014), Fagheh and Afshar (2012), Razavi and Salami (2013), Ashurizadeh, Maqdasi and Razavi (2013), Majidi (2017), and Hasan (2019). Globalization can be harmful to developing economies at the initial stage due to their inability to catch up with the emerging trend as depicted in the short run negative effect. As noted by Khor (2003), "Perhaps the most important and unique feature of the current globalization process is the 'globalization' of national policies and policy making mechanisms. National policies (including in economic, social, cultural and technological areas) that until recently were under the jurisdiction of States and people within a country have increasingly come under the influence of international agencies and processes or of big private corporations and economic/financial players. This has led to the erosion of national sovereignty and narrowed the ability of governments and people to make choices from options in economic, social and cultural policies". Thus, this act has made African countries to adopt policies which at times may be detrimental to their growth at that particular time. Such can be linked to the liberalization of markets and developments in technology which has a severe impact on capital flows. However, as African countries move along the learning curve, they will be able to match up with the global forces, compete favourable and boost her economic growth potentials in the long run.

All other variables in the short run are observed to exert an insignificant effect on economic growth. Foreign direct investment (FDIN) and unemployment (UNMR) exert positive and significant effect on economic growth of African countries in the long run. This implies that a unit percentage increase in FDIN and UNMR will lead to $13.08 \%$ and $12.68 \%$ increase in economic growth in the long run respectively. This finding stresses the importance of inflow of foreign direct investment to the economic growth of African countries since the region is characterized by insufficient resources that can tweak the economic growth of the region in a short period of time. The effect of FDIN can be both positive through new inflow and negative through outflow of investment income arising from the accumulated foreign capital stock.

It is important to note that unemployment will exert a positive and significant effect on economic growth in the long run. This is because the unemployment rate in the long run will be NAIRU - Non Accelerating Inflation Rate of Unemployment. Thus, an increase in unemployment will reduce inflation based on the Philips postulation. Assuming inflation is cost push, such decrease in inflation will translates to producers being able to buy more of raw material, employ more workers, and produce more output and thus leading to growth.

The error correction term is rightly signed (negative) and statistically significant at $1 \%$ level of significance. This implies that $78.21 \%$ of the short run disequilibrium is corrected annually. Thus, it will take one year and seven months for the model to be fully restored back to equilibrium.

4.5.2. Panel Vector Error Correction Mechanism for Equation (4)

The result is presented in Table 6 .

Table 6: Error Correction Mechanism Result for Model (4)

\begin{tabular}{|l|l|l|l|l|}
\hline Variable & Coefficient & Standard Error & t-statistic & Probability \\
\hline \multicolumn{5}{|c|}{ Long run Equation: UNMR $=\mathbf{0 . 0 7 5 K O F G I ~}$} \\
\hline KOFGI & 0.075292 & 0.009780 & 7.698783 & $0.0000^{* * *}$ \\
\hline \multicolumn{5}{|c|}{ Short Run Equation: $\Delta$ UNMR $=\mathbf{0 . 3 2 9}-\mathbf{0 . 0 4 0} \Delta$ KOFGI - 0.086ECMt-1 } \\
\hline ECM(-1) & -0.085616 & 0.025088 & -3.412589 & $0.0007 * * *$ \\
\hline D(KOFGI) & -0.040199 & 0.022120 & -1.817307 & $0.0697^{*}$ \\
\hline $\mathrm{C}$ & 0.329048 & 0.173777 & 1.893505 & $0.0588^{*}$ \\
\hline
\end{tabular}

Note: $* * *$ and $*$ indicates $1 \%$ and $10 \%$ level of significance respectively.

Source: Output Extracted from Eviews 10.

From Table 6, it is observed that a similar relationship exists between globalization and growth as well as globalization and unemployment. Thus, globalization has a negative and significant effect on unemployment in the short run but a positive and significant effect in the long run. This implies that a unit percentage increase in globalization will lead to a $7.52 \%$ increase in unemployment in the long run. Also, a unit percentage change in globalization will lead to a $4.0 \%$ percentage decrease in unemployment in the short run. Thus, globalization is beneficial to employment generation in the short run but detrimental in the long run. This upholds the view that globalization generates inequality but only in the long run. This is because in the short run, Africans can move to secure employment abroad but in the long run, the detrimental effect of brain drain and successive monopolization by foreign firms will lead to a fallout in the expected positive effect. The error correction term (0.086) measures the speed of adjustment of the short run dynamics to a long run equilibrium. Hence, about $8.56 \%$ of the short run disequilibrium is corrected annually.

\subsection{Cross Section Short Run Coefficients}

The elasticity of economic growth to globalization differs across countries in Africa. Some countries experience negative effects while others experience a positive effect. These dynamics is presented in Table 7. 
Table 7: Cross Country Short Run Regression Result

\begin{tabular}{|l|c|c|c|c|c|}
\hline \multicolumn{1}{|c|}{ Country } & Elasticity & Remarks & Country & Elasticity & Remarks \\
\hline Algeria & -0.189 & Significant & Madagascar & 1.352 & Significant \\
\hline Angola & -1.967 & Insignificant & Mauritania & 1.516 & Significant \\
\hline Benin & 0.518 & Significant & Morocco & -1.025 & Significant \\
\hline Burkina Faso & -0.039 & Insignificant & Mozambique & -0.241 & Insignificant \\
\hline Cameroon & -0.003 & Insignificant & Nigeria & -1.082 & Significant \\
\hline Central African Republic & -0.003 & Insignificant & Senegal & 0.875 & Significant \\
\hline Cote d'Ivoire & 0.763 & Significant & Sierra Leone & 1.895 & Insignificant \\
\hline Egypt & 0.190 & Significant & South Africa & 0.481 & Significant \\
\hline Equatorial Guinea & -5.070 & Insignificant & Sudan & 0.659 & Insignificant \\
\hline Ethiopia & -1.441 & Significant & Tanzania & 0.195 & Significant \\
\hline The Gambia & -1.047 & Significant & Tunisia & 0.384 & Significant \\
\hline Ghana & -0.471 & Significant & Zambia & 0.784 & Significant \\
\hline Kenya & 0.161 & Insignificant & Overall & -0.053 & Insignificant \\
\hline
\end{tabular}

Note: For detail, see Appendix 2.

Source: Output Extracted form Eviews 10.

From Table 7, it is observed that Mauritania experiences a greater positive and significant effect of globalization on her economic growth as evidenced in her elasticity coefficient of 1.516. Though the elasticity of Sierra Leone is the greatest (1.895), such is insignificant in influencing economic growth. Also, the country with the greatest burden of globalization on economic growth is Equatorial Guinea with elasticity coefficient of -5.070. However, such is not statistically significant (see the graph on Appendix 1 for the movements). Further, country with the least positive effect is Egypt (0.190) while Cameroon and Central African Republic are the ones bearing the least burden of globalization on economic growth. Overall, African experiences a negative and insignificant effect of globalization on economic growth in the short run with an elasticity coefficient of -0.053 .

\subsection{Granger Causality Test}

The result of the Dumitrescu and Hurlin (2012) Granger Causality test is presented in Table 8.

Table 8: Pairwise Dumitrescu Hurlin Panel Causality Tests Result

\begin{tabular}{lccr}
\hline \hline Null Hypothesis: & W-Stat. & Zbar-Stat. & Prob. \\
\hline \hline KOFGI does not homogeneously cause RGDPG & 4.37799 & 4.33841 & $0.0000^{* *}$ \\
RGDPG does not homogeneously cause KOFGI & 3.46409 & 2.49920 & $0.0124^{*}$ \\
\hline \hline
\end{tabular}

Note: $* *$ and $*$ denotes significance at $1 \%$ and $5 \%$ respectively.

Source: Output Extracted from Eviews 10.

From Table 8, there is an evidence of a bi-directional causality between globalization and economic growth. Thus, globalization homogeneously cause economic growth and economic growth also homogeneously cause globalization. This result is an indication that though globalization is growth promoting, the growth of the African economy is also a basis for globalization.

\section{Conclusion and Recommendations}

\subsection{Conclusion}

Globalization has been viewed as the concentration and monopolization of economic resources and power by transnational corporations and by global firms and funds (Khor, 2003). This has been the central view of some policy makers in developing countries thereby painting a negative effect of globalization on economic growth of developing countries. One of the reason for this view has been that African countries are mainly exporters of primary products hence; they may not fully benefit form globalization. This line of thinking is somewhat skewed since globalization is not only measured through trade openness. However, individuals and some policy makers have aligned with the view that globalization leads to competition, innovation and knowledge driven economy. The findings of this study has revealed that globalization exerts a positive and significant long run effect on the economic growth of African countries. Thus, a unit percentage increase in the index of globalization will lead to a $5.69 \%$ increase in economic growth in the long run. Though some African countries may experience a short run negative effect (See Appendix 2) due to their structural dissimilarities, such negative effect will be eroded in the long run when such countries have passed through the learning curve. Other variables such as foreign direct investment and unemployment are observed to exert a positive and significant long run effect on economic growth while inflation exerts a positive but insignificant effect. This implies that a unit percentage increase in FDIN and UNMR will result to a $13.08 \%$ and $12.68 \%$ increase in economic growth respectively. The long run equilibrium 
relationship as reported by the error correction term indicates that $78.21 \%$ of the short run disequilibrium is corrected annually. Also, the study revealed a positive and significant effect of globalization on unemployment in the long run but a negative and significant effect in the short run. Meanwhile, $8.56 \%$ of the short run dynamic disequilibrium is corrected annually. The Granger Causality test showed that there is a bidirectional causality between globalization and economic growth in Africa.

\subsection{Recommendations}

Based on the findings of this study, the following recommendations are proffered:

1. Globalization is observed to have a positive and significant long run effect on economic growth of Africa hence, African countries should realize the long run importance of globalization as a powerful force that drives a modern economy hence, coherent policies should be developed and geared towards managing the excesses of globalization so as to move along with the ever evolving world.

2. Globalization is a necessity in the $21^{\text {st }}$ century. Though some African countries may not receive a short run positive effect, the effects will be magnanimous in the long run. African countries need to embrace globalization since through this, knowledge, information, ideas, technology, and the like are transferred. However, there is need for careful management of the globalization process to suit the level of development of a particular country. However, to ensure fairness and equity in the globalized world, African countries should be given more rights of participation in decision making processes in key institutions such as the IMF, World Bank and WTO in order to alley the fear of bleak prospects in the Africa of $21^{\text {st }}$ century.

3. Since the study also revealed that foreign direct investment is growth promoting, African countries should ensure that they meet the following conditions as stipulated by Ghazali (1996) and cited in Khor (2003):

i. $\quad$ Availability of foreign capital should not detract from African countries' savings effort;

ii. $\quad$ The factor payment cost must be minimized and prudently managed;

iii. African countries should encourage or require joint ventures so that part of the returns accrues to locals and is retained by the local economy;

iv. African countries should get foreign firms to list themselves on local bourses;

v. FDI should be concentrated in the tradeable sector, especially in export-based activities to enhance positive trade effects;

vi. $\quad$ Local content of output should be raised over time to improve the trade effect;

vii. The growth of domestic investment should exceed FDI growth; and

viii. African countries should increase their savings rate and maintain sound economic and political conditions to avoid over reliance on foreign capital.

\section{References}

Ashurizadeh, A., Maqdasi, M. and Razavi, S. (2013), "The effect of economic globalization and trade on economic growth of VAR model", First Electronic Conference National of View of Iranian Economic with Approach of Support National Production.

Barry, H. (2010), "Globalization and economic growth in sub-Saharan Africa", Gettysburg Economic Review, 4, 42 - 86. http://cupola.gettysburg.edu/ger/vol4/iss1/4

Bhaskara, V. and Krishna, C. (2011), "Globalization and growth in the low income African countries with the extreme bounds analysis", Economic Modelling, 28(3), 795 - 805.

Bhattacharya, D. (2004), "Globalization and the state: human development and capacity building needs - a review of Asian countries experiences. Globalization and the State: challenges for economic growth and human development", Department of Economic and Social Affairs, New York.

Clark, W.C. (2000), "Environmental globalization”, In: Governance in a Globalizing World (eds. Joseph, S. N. and J. D. Donahue), Brookings Institution Press, Washington, D.C.

Dreher, A. (2005), "Globalization and taxation in the OECD: Evidence from a new indicator of integration", Public Financial Management, 5(3), 400 - 420.

Dreher, A. (2006), "Does globalization affect growth? Empirical evidence from a new index of globalization", Applied Economics, 38(10), 1091 - 1110.

Dreher, A., Gaston, N. and Martens, P. (2008), "Measuring globalization - gauging its consequence", Springer, New York.

Dumitrescu, E. and Hurlin, C. (2012), “Testing for Granger non-causality in heterogeneous panels", Economic Modelling, 29(4), 1450 - 1460.

Eth, Z. (2019), "KOF Globalization Index”, KOF Swiss Economic Institute. https://kof.ethz.ch/en/forecast-andindicators/indicators/kof-globalization-index.html

Fagheh, M. A. and Afshar, P. A. (2012), "Examining the relationship between globalization and economic growth in the Middle East and North Africa", Political Economy, 26(290), 101 - 192. 
Ghazali, B. A. (1996), “The effects of FDI on trade, balance of payments and growth in developing countries: An appropriate policy to FDI", Penang, Malaysia: Third World Network.

Gurgul, H. and Lach, L. (2014), "Globalization and economic growth: Evidence from two decades of transition in CEE”, Economic Modelling, 36, 99 - 107.

Hasan, M. A. (2019), "Does globalization accelerate economic growth? South Asian experience using panel data", Journal of Economic Structures, 8(26). https://doi.org/10.1186/s40008-019-0159-x

Im, K. S., Pesaran, M. H. and Shin, Y. (2003), "Testing for unit roots in heterogeneous panels", Journal of Econometrics, 115(1), 53-74.

Keohane, R. O. and Nye, J. S. (2000), "Introduction”, In: Governance in a Globalizing World (eds. Joseph, S. N. and J. D. Donahue), Brookings Institution Press, Washington, D.C.

Khor, M. (2003), "Globalization ant the south: Some critical issues", Ibadan, Nigeria: Spectrum Books Limited.

Kilic, C. (2015), "Effects of globalization on economic growth: panel data analysis for developing countries", Economic Insights Trends Challenges, 4(127), 1-11.

KOF (2017), "Index of globalization". http:/globalization.kof.ethz.ch/

Levin, A., Lin, C. and Chu, C. J. (2002), "Unit root tests in panel data: asymptotic and finite-sample properties", Journal of Econometrics, 108, 1 - 24.

Lopez, L. and Weber, S. (2017), "Testing for Granger causality in panel data", IRENE Working Paper, University of Neuchatel Institute of Economic Research.

Majidi, A. F. (2017), "Globalization and economic growth: the case study of developing countries", Asian Economic and Financial Review, 7(6), 589 - 599. DOI: 10.18488/journal.aefr.2017.76.589.599

Maqbool-ur-Rahman, M. (2015), "Impacts of globalization on economic growth-evidence from selected South Asian countries", Journal of Management Sciences, $2(1), \quad 185 \quad-\quad 204$. https://doi.org/10.20547/jms.2014.1502103

Nahavandian, M. and Ghanbari, M. F. A. (2004), "We and globalization", Tehran: Institute for Humanities and Cultural Studies.

Norris, P. (2000), "Global governance and cosmopolitan citizens", In: Governance in a Globalizing World (eds. Joseph, S. N. and J. D. Donahue), Brookings Institution Press, Washington, D.C.

Omidvar, H. and Daryabeigi, M. (2011), "Globalization and international relations", Tehran: Afraz Publishing.

Pedroni, P. (2004), "Panel cointegration: asymptotic and finite sample properties of pooled time series test with an application to the PPP hypothesis", Econometric Theory, 20(3), 597 - 625.

Pishgah, H. H. (2002), “Terrorism and armed conflict", Journal of Africa Studies, 4(3).

Polasek W. and Sellner, R. (2011), "Does globalization affect regional growth? Evidence for NUTS-2 regions in EU-27", Economics series 266, Institute for Advanced Studies, Vienna.

Potrafke, N. (2005), "The evidence of globalization", The World Economy, 38(3), 509 - 552.

Rao, B. and Vadlamannati, K. (2011), "Globalization and growth in the low income African countries with the extreme bounds analysis", Economic Modelling, 28(3), 795 - 805.

Razavi, S. and Salimi, F. M. (2013), "The impact of economic globalization on economic growth by using VAR method", Globalization Strategic Journal, 4(12), 9 - 23.

Savina, G., Haelg, F. Potrafke, N. and Sturm, J. (2019), “The KOF Globalization Index - Revisited”, Review of International Organizations, 14(3), 543 - 574. https://doi.org/10.1007/s11558-019-09344-2

Taheri, H. and Taheri, P. (1964), "Globalization and its dimensions", Kaboudrahang: Kaboudrahang Press of Jam Jamshid.

Torado, M. P. and Smith, S. C. (2011), "Economic development", (eleventh edition), Harlow: Pearson Education.

World Bank (2017a), "World development indicators data". https://data.worldbank.org/data-catalog/worlddevelopment-indicators

World Bank (2018). "World Development Indicators".

Ying, Y., Chang, K. and Lee C. (2014), "The impact of globalization on economic growth", Roman Journal of Economic Forecasting, XVII (2), 25 - 34 


\section{Appendices}

Appendix 1: Stylized Facts on Cross Country Trend of RGDPG and KOGFI

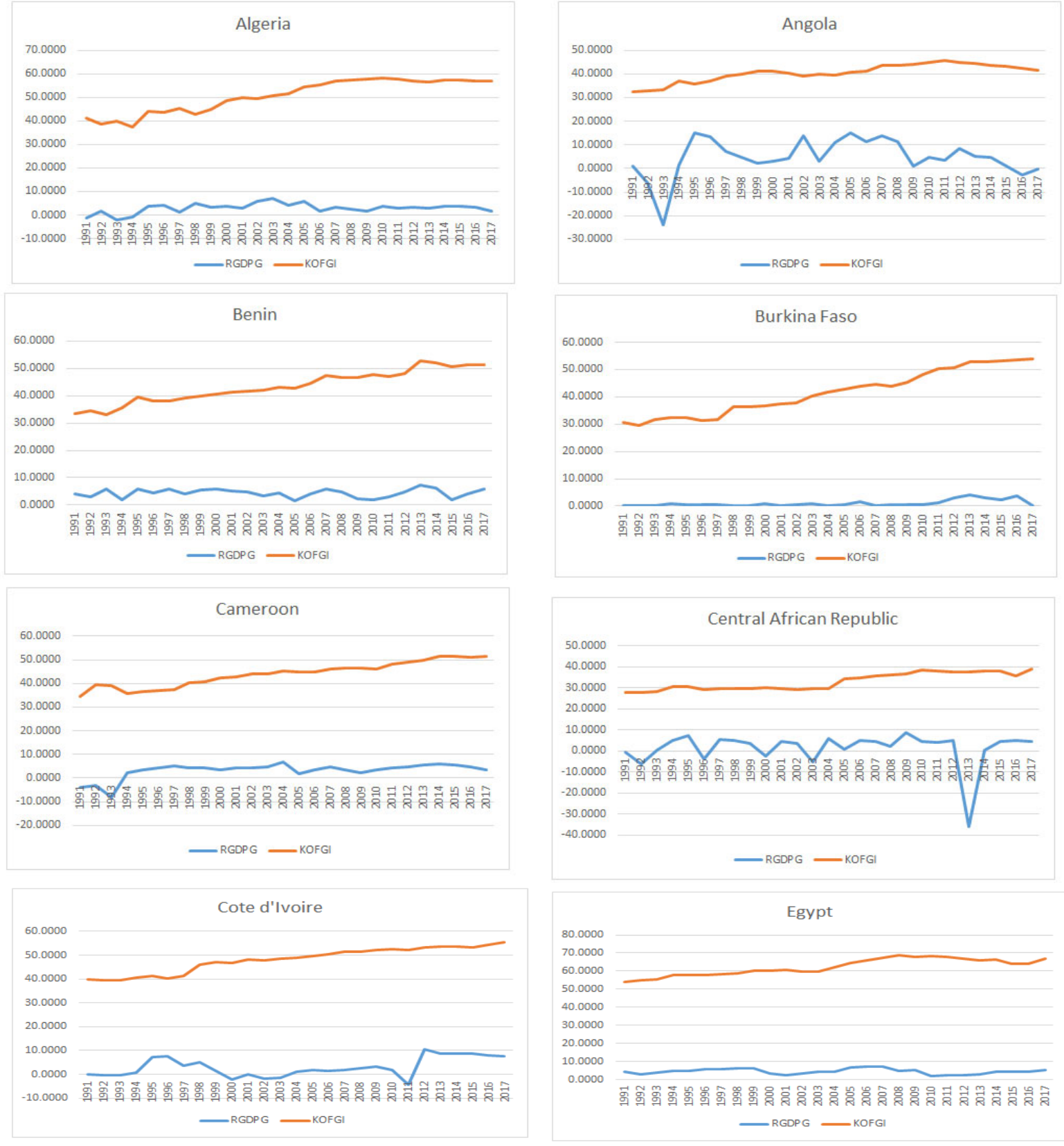




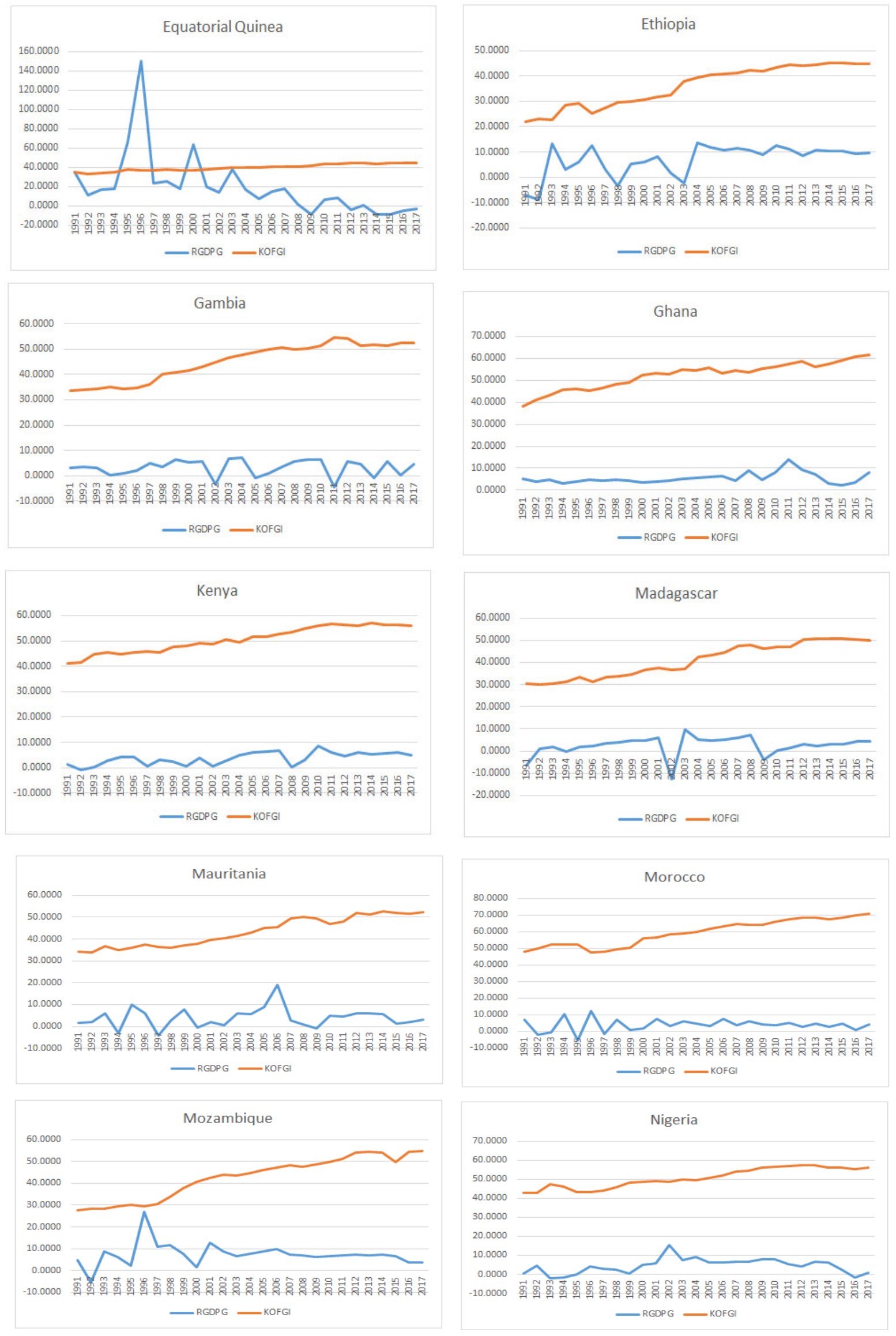




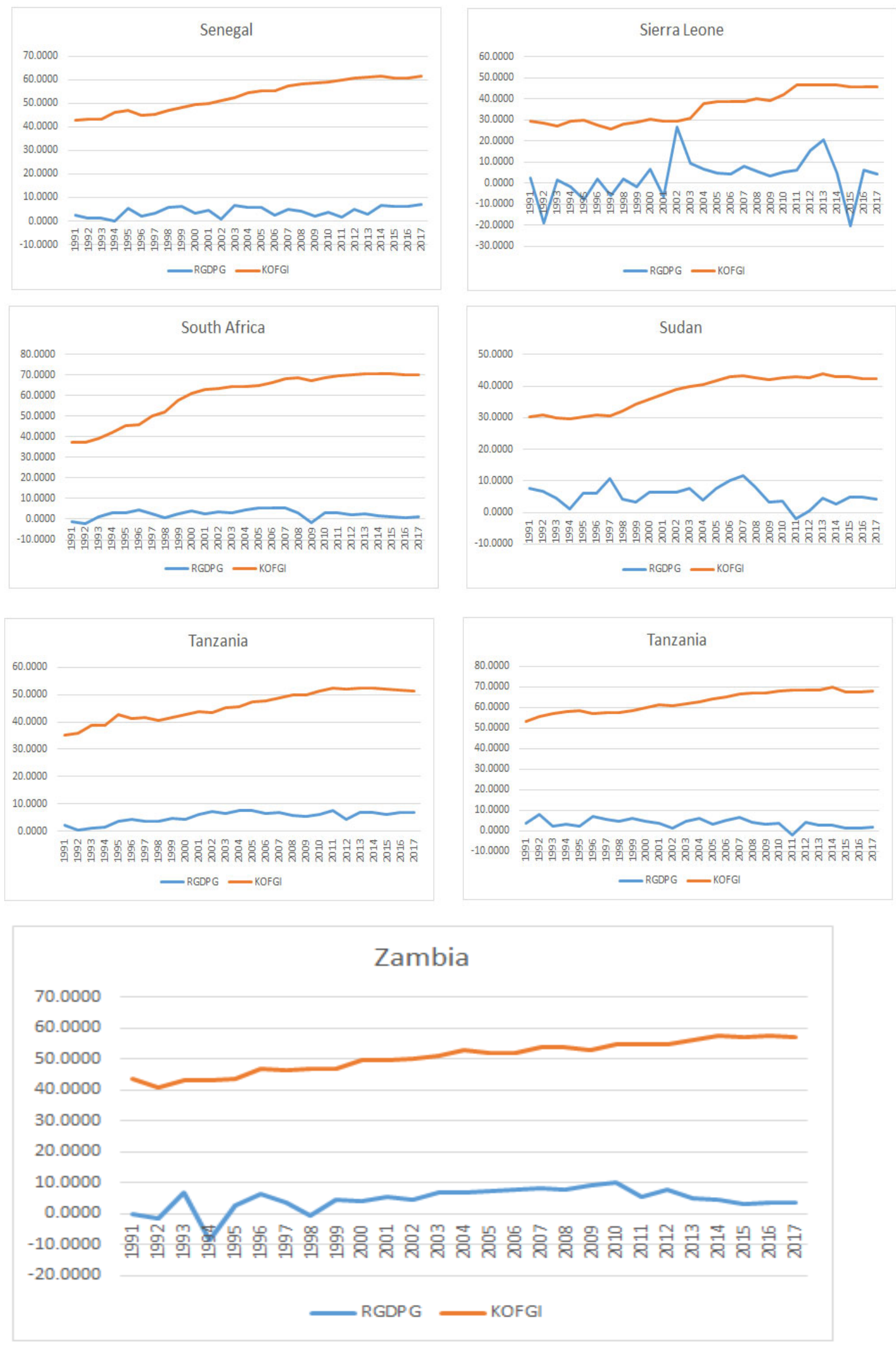




\section{Appendix 2: Cross Section Short Run Coefficients}

\begin{tabular}{|c|c|c|c|c|}
\hline Variable & Coefficient & Std. Error & t-Statistic & Prob. ${ }^{*}$ \\
\hline COINTEQ01 & -1.206397 & 0.066768 & -18.06850 & 0.0004 \\
\hline D(KOFGl) & -0.188719 & 0.045015 & -4.192324 & 0.0248 \\
\hline $\mathrm{D}(\mathrm{FDIN})$ & -1.205075 & 0.236575 & -5.093832 & 0.0146 \\
\hline $\mathrm{D}(\mathrm{NNFL})$ & 0.166216 & 0.005949 & 27.94217 & 0.0001 \\
\hline D(UNMR) & -0.293508 & 0.038980 & -7.529752 & 0.0049 \\
\hline C & -2.182146 & 2.068402 & -1.054992 & 0.3689 \\
\hline \multicolumn{5}{|l|}{ Benin } \\
\hline Variable & Coefficient & Std. Error & t-Statistic & Prob. * \\
\hline COINTEQ01 & -0.617676 & 0.026115 & -23.65244 & 0.0002 \\
\hline D(KOFGI) & 0.517754 & 0.020711 & 24.99887 & 0.0001 \\
\hline $\mathrm{D}(\mathrm{FDIN})$ & 0.382017 & 0.029721 & 12.85341 & 0.0010 \\
\hline $\mathrm{D}(\mathrm{INFL})$ & -0.043590 & 0.000762 & -57.22606 & 0.0000 \\
\hline D(UNMR) & -0.108584 & 0.503956 & -0.215463 & 0.8432 \\
\hline $\mathrm{C}$ & 0.601153 & 0.370323 & 1.623319 & 0.2030 \\
\hline \multicolumn{5}{|c|}{ Cameroon } \\
\hline Variable & Coefficient & Std. Error & t-Statistic & Prob. * \\
\hline COINTEQ01 & -0.301908 & 0.024157 & -12.49782 & 0.0011 \\
\hline $\mathrm{D}(\mathrm{KOFGI})$ & -0.002569 & 0.096217 & -0.026703 & 0.9804 \\
\hline $\mathrm{D}(\mathrm{FDIN})$ & -0.230252 & 0.073532 & -3.131302 & 0.0520 \\
\hline $\mathrm{D}(\mathrm{INFL})$ & 0.102319 & 0.002846 & 35.94813 & 0.0000 \\
\hline D(UNMR) & -0.758036 & 1.226210 & -0.618195 & 0.5802 \\
\hline $\mathrm{C}$ & 0.119177 & 0.264360 & 0.450813 & 0.6827 \\
\hline \multicolumn{5}{|c|}{ Cote d'Ivoire } \\
\hline Variable & Coefficient & Std. Error & t-Statistic & Prob. * \\
\hline COINTEQ01 & -0.667595 & 0.023130 & -28.86306 & 0.0001 \\
\hline $\mathrm{D}(\mathrm{KOFGI})$ & 0.763125 & 0.276304 & 2.761900 & 0.0700 \\
\hline $\mathrm{D}(\mathrm{FDIN})$ & -0.018748 & 0.435945 & -0.043005 & 0.9684 \\
\hline $\mathrm{D}(\mathrm{INFL})$ & -0.247998 & 0.008470 & -29.27789 & 0.0001 \\
\hline D(UNMR) & -2.361628 & 0.799678 & -2.953225 & 0.0599 \\
\hline C & -1.023595 & 0.748724 & -1.367119 & 0.2650 \\
\hline
\end{tabular}

\begin{tabular}{ccccc}
\hline \multicolumn{6}{c}{ Angola } & & & \\
\hline \hline Variable & Coefficient & Std. Error & t-Statistic & Prob. * \\
\hline COINTEQ01 & -0.787047 & 0.042779 & -18.39778 & 0.0004 \\
D(KOFGI) & -1.966510 & 2.627808 & -0.748346 & 0.5086 \\
D(FDIN) & -0.193740 & 0.015519 & -12.48433 & 0.0011 \\
D(INFL) & -0.003336 & $5.42 E-06$ & -615.7822 & 0.0000 \\
D(UNMR) & -3.035743 & 2.300295 & -1.319719 & 0.2786 \\
C & -2.476769 & 3.553537 & -0.696987 & 0.5360 \\
\hline \hline
\end{tabular}

\begin{tabular}{crrrr}
\multicolumn{5}{c}{ Equatorial Guinea } \\
\hline \hline Variable & Coefficient & Std. Error & t-Statistic & Prob. * \\
\hline \hline COINTEQ01 & -0.504571 & 0.025450 & -19.82613 & 0.0003 \\
D(KOFGI) & -5.069507 & 19.71600 & -0.257127 & 0.8137 \\
D(FDIN) & 0.332375 & 0.023848 & 13.93717 & 0.0008 \\
D(INFL) & -1.106402 & 0.287227 & -3.852005 & 0.0309 \\
D(UNMR) & -18.44502 & 216.3418 & -0.085259 & 0.9374 \\
C & 8.891844 & 22.62179 & 0.393065 & 0.7205
\end{tabular}

\begin{tabular}{crrrr}
\hline \hline \multicolumn{5}{c}{ Gambia } \\
\hline \hline Variable & Coefficient & Std. Error & t-Statistic & Prob. * $^{*}$ \\
\hline \hline COINTEQ01 & -1.163043 & 0.045790 & -25.39966 & 0.0001 \\
D(KOFGI) & -1.047408 & 0.311200 & -3.365713 & 0.0435 \\
D(FDIN) & -0.128540 & 0.110586 & -1.162355 & 0.3292 \\
D(INFL) & 0.175650 & 0.032155 & 5.462665 & 0.0121 \\
D(UNMR) & -0.642616 & 8.217400 & -0.078202 & 0.9426 \\
C & -1.098040 & 1.597280 & -0.687444 & 0.5412 \\
\hline \hline
\end{tabular}

\begin{tabular}{crrrr}
\hline \multicolumn{6}{c}{ Kenya } & & & \\
\hline \hline Variable & Coefficient & Std. Error & t-Statistic & Prob. * \\
\hline COINTEQ01 & -0.713677 & 0.041940 & -17.01677 & 0.0004 \\
D(KOFGI) & 0.160917 & 0.134688 & 1.194735 & 0.3180 \\
D(FDIN) & 0.443624 & 0.101124 & 4.386918 & 0.0219 \\
D(INFL) & -0.130586 & 0.001533 & -85.16565 & 0.0000 \\
D(UNMR) & -3.373620 & 3.976233 & -0.848446 & 0.4585 \\
C & -0.395390 & 0.649333 & -0.608917 & 0.5856 \\
\hline \hline
\end{tabular}

\begin{tabular}{|c|c|c|c|c|}
\hline \multicolumn{5}{|c|}{ Burkina Faso } \\
\hline Variable & Coefficient & Std. Error & t-Statistic & Prob. * \\
\hline COINTEQ01 & -0.853503 & 0.094930 & -8.990883 & 0.0029 \\
\hline $\mathrm{D}(\mathrm{KOFGI})$ & -0.039170 & 0.021273 & -1.841264 & 0.1628 \\
\hline $\mathrm{D}(\mathrm{FDIN})$ & 0.014129 & 0.081515 & 0.173333 & 0.8734 \\
\hline $\mathrm{D}(\mathrm{INFL})$ & 0.006301 & 0.000551 & 11.43293 & 0.0014 \\
\hline $\mathrm{D}$ (UNMR) & -0.186827 & 0.599773 & -0.311495 & 0.7758 \\
\hline $\mathrm{C}$ & -1.580654 & 0.791117 & -1.998003 & 0.1396 \\
\hline \multicolumn{5}{|c|}{ Central Afican Republic } \\
\hline Variable & Coefficient & Std. Error & $\mathrm{t}$-Statistic & Prob. * \\
\hline COINTEQ01 & -0.301908 & 0.024157 & -12.49782 & 0.0011 \\
\hline $\mathrm{D}(\mathrm{KOFGI})$ & -0.002569 & 0.096217 & -0.026703 & 0.9804 \\
\hline $\mathrm{D}(\mathrm{FDIN})$ & -0.230252 & 0.073532 & -3.131302 & 0.0520 \\
\hline $\mathrm{D}(\mathrm{INFL})$ & 0.102319 & 0.002846 & 35.94813 & 0.0000 \\
\hline $\mathrm{D}(\mathrm{UNMR})$ & -0.758036 & 1.226210 & -0.618195 & 0.5802 \\
\hline C & 0.119177 & 0.264360 & 0.450813 & 0.6827 \\
\hline \multicolumn{5}{|c|}{ Egypt } \\
\hline Variable & Coefficient & Std. Error & t-Statistic & Prob. * \\
\hline COINTEQ01 & -0.463157 & 0.031780 & -14.57398 & 0.0007 \\
\hline $\mathrm{D}(\mathrm{KOFGI})$ & 0.189709 & 0.047959 & 3.955661 & 0.0288 \\
\hline $\mathrm{D}(\mathrm{FDIN})$ & 0.215274 & 0.024709 & 8.712531 & 0.0032 \\
\hline $\mathrm{D}(\mathrm{INFL})$ & -0.020940 & 0.001968 & -10.63744 & 0.0018 \\
\hline D(UNMR) & -0.082933 & 0.062997 & -1.316463 & 0.2796 \\
\hline $\mathrm{C}$ & -0.433181 & 0.355303 & -1.219187 & 0.3099 \\
\hline \multicolumn{5}{|c|}{ Ethiopia } \\
\hline Variable & Coefficient & Std. Error & t-Statistic & Prob. * \\
\hline COINTEQ01 & -0.958932 & 0.018407 & -52.09613 & 0.0000 \\
\hline $\mathrm{D}(\mathrm{KOFGI})$ & -1.440591 & 0.212618 & -6.775474 & 0.0066 \\
\hline $\mathrm{D}(\mathrm{FDIN})$ & -0.208903 & 0.250698 & -0.833284 & 0.4658 \\
\hline $\mathrm{D}(\mathrm{INFL})$ & -0.003321 & 0.004197 & -0.791433 & 0.4865 \\
\hline D(UNMR) & -3.917160 & 25.45469 & -0.153888 & 0.8875 \\
\hline C & 6.246332 & 1.376181 & 4.538888 & 0.0200 \\
\hline \multicolumn{5}{|c|}{ Ghana } \\
\hline Variable & Coefficient & Std. Error & t-Statistic & Prob. * \\
\hline COINTEQ01 & -0.613964 & 0.030153 & -20.36173 & 0.0003 \\
\hline $\mathrm{D}(\mathrm{KOFGI})$ & -0.471478 & 0.092514 & -5.096277 & 0.0146 \\
\hline $\mathrm{D}(\mathrm{FDIN})$ & 0.144296 & 0.078823 & 1.830622 & 0.1646 \\
\hline $\mathrm{D}(\mathrm{INFL})$ & -0.006120 & 0.001355 & -4.515080 & 0.0203 \\
\hline D(UNMR) & 0.052130 & 0.368495 & 0.141467 & 0.8965 \\
\hline C & 1.074625 & 0.589274 & 1.823643 & 0.1657 \\
\hline \multicolumn{5}{|c|}{ Madagascar } \\
\hline Variable & Coefficient & Std. Error & t-Statistic & Prob. * \\
\hline COINTEQ01 & -1.258344 & 0.028164 & -44.67863 & 0.0000 \\
\hline $\mathrm{D}(\mathrm{KOFGI})$ & 1.352371 & 0.254940 & 5.304660 & 0.0131 \\
\hline $\mathrm{D}(\mathrm{FDIN})$ & 0.399665 & 0.122438 & 3.264227 & 0.0470 \\
\hline $\mathrm{D}(\mathrm{INFL})$ & -0.137418 & 0.004694 & -29.27499 & 0.0001 \\
\hline D(UNMR) & 0.046840 & 1.125763 & 0.041607 & 0.9694 \\
\hline C & -1.882949 & 1.304391 & -1.443547 & 0.2446 \\
\hline
\end{tabular}


Mauritania

\begin{tabular}{|c|c|c|c|c|}
\hline Variable & Coefficient & Std. Error & t-Statistic & Prob. * \\
\hline COINTEQ01 & -1.289986 & 0.032029 & -40.27596 & 0.0000 \\
\hline $\mathrm{D}(\mathrm{KOFGI})$ & 1.515903 & 0.258154 & 5.872084 & 0.0099 \\
\hline $\mathrm{D}(\mathrm{FDIN})$ & -0.404534 & 0.012015 & -33.66863 & 0.0001 \\
\hline D(INFL) & 0.314571 & 0.076464 & 4.113953 & 0.0260 \\
\hline D(UNMR) & -0.515539 & 1.907190 & -0.270313 & 0.8044 \\
\hline C & -2.015958 & 1.803937 & -1.117533 & 0.3452 \\
\hline \multicolumn{5}{|c|}{ Mozambique } \\
\hline Variable & Coefficient & Std. Error & t-Statistic & Prob. * \\
\hline COINTEQ01 & -0.697582 & 0.038884 & -17.94004 & 0.0004 \\
\hline $\mathrm{D}(\mathrm{KOFGI})$ & -0.240848 & 0.479930 & -0.501839 & 0.6503 \\
\hline $\mathrm{D}(\mathrm{FDIN})$ & 0.124030 & 0.043685 & 2.839194 & 0.0657 \\
\hline D(INFL) & 0.081831 & 0.007015 & 11.66533 & 0.0014 \\
\hline D(UNMR) & 11.64694 & 36.11195 & 0.322523 & 0.7682 \\
\hline C & 2.251136 & 2.231950 & 1.008596 & 0.3875 \\
\hline
\end{tabular}

Senegal

\begin{tabular}{crrrr}
\hline \hline Variable & Coefficient & Std. Error & t-Statistic & Prob. $^{*}$ \\
\hline \hline COINTEQ01 & -0.689811 & 0.035827 & -19.25407 & 0.0003 \\
D(KOFGI) & 0.874782 & 0.178810 & 4.892243 & 0.0163 \\
D(FDIN) & -0.110980 & 0.182860 & -0.606914 & 0.5868 \\
D(INFL) & -0.128140 & 0.002590 & -49.47104 & 0.0000 \\
D(UNMR) & -0.514556 & 0.333725 & -1.541854 & 0.2208 \\
C & -0.630060 & 0.651081 & -0.967713 & 0.4046 \\
\hline \hline
\end{tabular}

South Africa

\begin{tabular}{crrrr}
\hline \hline Variable & Coefficient & Std. Error & t-Statistic & Prob. * \\
\hline \hline COINTEQ01 & -0.786286 & 0.048702 & -16.14500 & 0.0005 \\
D(KOFGI) & 0.480720 & 0.032341 & 14.86411 & 0.0007 \\
D(FDIN) & -0.196490 & 0.026316 & -7.466583 & 0.0050 \\
D(INFL) & 0.080069 & 0.017358 & 4.612714 & 0.0192 \\
D(UNMR) & -0.454413 & 0.070467 & -6.448598 & 0.0076 \\
C & -4.191864 & 2.733887 & -1.533298 & 0.2227 \\
\hline \hline & & & & \\
\hline \hline & & & & \\
\hline \hline & & & & \\
Variable & Coefficient & Std. Error & t-Statistic & Prob. * \\
COINTEQ01 & -0.174894 & 0.013993 & -12.49909 & 0.0011 \\
D(KOFGI) & 0.195043 & 0.036268 & 5.377829 & 0.0126 \\
D(FDIN) & -0.111445 & 0.023583 & -4.725555 & 0.0180 \\
D(INFL) & -0.073447 & 0.002422 & -30.32553 & 0.0001 \\
D(UNMR) & 0.994185 & 0.520233 & 1.911040 & 0.1520 \\
C & 0.369711 & 0.127006 & 2.910967 & 0.0619 \\
\hline \hline
\end{tabular}

Morocco

\begin{tabular}{crrrr}
\hline \hline Variable & Coefficient & Std. Error & t-Statistic & Prob. $^{*}$ \\
\hline \hline COINTEQ01 & -1.660577 & 0.012536 & -132.4653 & 0.0000 \\
D(KOFGI) & -1.025471 & 0.079945 & -12.82727 & 0.0010 \\
D(FDIN) & 0.557161 & 0.138484 & 4.023287 & 0.0276 \\
D(INFL) & 0.138505 & 0.098140 & 1.411294 & 0.2530 \\
D(UNMR) & -3.093085 & 0.862344 & -3.586834 & 0.0371 \\
C & -1.622717 & 3.908997 & -0.415124 & 0.7060 \\
\hline \hline & Nigeria & & & \\
\hline \hline Variable & Coefficient & Std. Error & t-Statistic & Prob. ${ }^{*}$ \\
\hline \hline COINTEQ01 & -0.324274 & 0.021591 & -15.01889 & 0.0006 \\
D(KOFGI) & -1.081629 & 0.294735 & -3.669838 & 0.0350 \\
D(FDIN) & 0.364458 & 0.462806 & 0.787496 & 0.4885 \\
D(INFL) & -0.036095 & 0.001808 & -19.96192 & 0.0003 \\
D(UNMR) & -4.595321 & 3.922882 & -1.171414 & 0.3260 \\
C & 1.295574 & 0.513198 & 2.524509 & 0.0858 \\
\hline \hline & & & & \\
\hline \hline & Sierra Leone & & & \\
\hline \hline Variable & Coefficient & Std. Error & \multirow{2}{*}{ t-Statistic } & Prob. * \\
\hline \hline COINTEQ01 & -0.898814 & 0.038279 & -23.48041 & 0.0002 \\
D(KOFGI) & 1.894749 & 0.950932 & 1.992519 & 0.1403 \\
D(FDIN) & -0.294820 & 0.095622 & -3.083186 & 0.0540 \\
D(INFL) & -0.135679 & 0.005096 & -26.62522 & 0.0001 \\
D(UNMR) & 4.432381 & 125.3987 & 0.035346 & 0.9740 \\
C & -2.011592 & 3.753381 & -0.535941 & 0.6292 \\
\hline \hline & & & &
\end{tabular}

Sudan

\begin{tabular}{crrrr}
\hline \hline Variable & Coefficient & Std. Error & t-Statistic & Prob. $^{*}$ \\
\hline \hline COINTEQ01 & -0.491083 & 0.030531 & -16.08464 & 0.0005 \\
D(KOFGI) & 0.658861 & 0.343798 & 1.916420 & 0.1512 \\
D(FDIN) & -0.601752 & 0.246982 & -2.436424 & 0.0928 \\
D(INFL) & -0.014202 & 0.000388 & -36.58688 & 0.0000 \\
D(UNMR) & 0.598592 & 1.369738 & 0.437012 & 0.6916 \\
C & 0.016624 & 0.528897 & 0.031431 & 0.9769 \\
\hline \hline & \multirow{2}{*}{ Tunisia } & & & \\
\hline \hline Variable & Coefficient & \multirow{2}{*}{ Std. Error } & \multirow{2}{*}{-Statistic } & Prob. * \\
\hline \hline COINTEQ01 & -0.776502 & 0.029045 & -26.73459 & \multirow{2}{*}{0.0001} \\
D(KOFGI) & 0.383897 & 0.151874 & 2.527732 & 0.0856 \\
D(FDIN) & 0.017377 & 0.028997 & 0.599293 & 0.5912 \\
D(INFL) & -0.027320 & 0.002472 & -11.05351 & 0.0016 \\
D(UNMR) & -0.731926 & 0.170196 & -4.300491 & 0.0231 \\
C & -1.848128 & 1.243152 & -1.486647 & 0.2338 \\
\hline \hline
\end{tabular}

\section{Zambia}

\begin{tabular}{crrrr}
\hline \hline Variable & Coefficient & Std. Error & t-Statistic & Prob. * \\
\hline \hline COINTEQ01 & -0.582178 & 0.019398 & -30.01265 & 0.0001 \\
D(KOFGI) & 0.784325 & 0.201036 & 3.901414 & 0.0299 \\
D(FDIN) & 0.279654 & 0.042796 & 6.534577 & 0.0073 \\
D(INFL) & 0.055239 & 0.000449 & 122.8900 & 0.0000 \\
D(UNMR) & 0.178017 & 0.122151 & 1.457356 & 0.2411 \\
C & -0.366278 & 0.686320 & -0.533684 & 0.6306 \\
\hline \hline
\end{tabular}

